\title{
PODCAST IMPACTS ON STUDENTS' LISTENING SKILL: A CASE STUDY BASED ON STUDENTS' PERCEPTIONS
}

\author{
Oleh \\ Sartika Dewi Harahap \\ Sekolah Tinggi Agama Islam Negeri Mandailing Natal \\ Email: toti.ndaay@gmail.com
}

\begin{abstract}
Technology has produced prominent contribution on education in this information age. It is well known as Edu technology. The podcast is an alternative teaching media to support students' Listening Skill. In development of ICT, Podcast is a digital recording which contains a recorded program from television, radio, and interviews by using the internet. The present study was aimed to explore podcast effects on Listening Skill for university students. This study involved fourteen students on second semester of Tadris Bahasa Inggris Sekolah Tinggi Agama Islam Negeri Mandailing Natal as participants. Questionnaire and interview were the instruments used in this study to collect the data. In conclusion, students moderately engage themselves to sharpen their English namely listening with technology experiences. Most of the participants agreed that they like podcast because it helped them in learning English. Podcast provided tremendous topics and activities which make both teachers and students enrich their knowledge and develop their English skills in educational purposes.
\end{abstract}

Keywords : Podcasts, Students' Listening Skill, Students Perceptions \& Technology.

\section{INTRODUCTION}

Nowadays being able to speak English are essential for people to communicate with global community (Samad and Fitriani, 2016). Particularly listening, it is indeed true as the most commonly heard and much engaged-in language sub-skill in English. To help nonnative speakers to learn to speak and listen the language, there are many kinds of technologies invented. According to Marshall (2002:18), new opportunities can be gained by using technology. It offers users to connect with people around the world and gives a lot of unique perspectives and experiences. The podcast can also be used as supplementary lecture materials and off-campus learning also in online teaching in this pandemic era. This unfortunate condition has sure mostly contributed much to the poor achievement of Indonesian students' in listening.

The use of technology in language learning may vary, for instance, as a media for teaching and learning language. One of the most influencing media in language learning is audio media. Traditional audio media formats such as vinyl, cassettes, CDs and DVDs have been used for decades. The benefits mostly come from its practical use that makes language learning easier and more satisfying. Furthermore, as the technology continues to develop, the use of audio media in language learning becomes more satisfying. According to Rossel-Aguilar (2013), since the arrivals of the digital era, audio media utilization in teaching language has become easier to use. It goes online through the use of websites, online learning environments, learning management systems and podcast.

Using podcast as media, the teacher can support the students in building selfconfidence and the learning situation enjoyable. Rajpal et al. (2011) describe Podcast as "a standard digital audio and video broadcast that can be downloaded and played in mobile devices, iPhones and iPods". It content will cover a wide range of topics such as songs, jokes, stories, poems, or some specific language features such as pronunciation, vocabulary and 
grammar that can be applied as a source of materials for teaching. Listeners do not need to visit every website frequently for new podcast episodes; they can now find a huge collection of podcasts on iTunes store. Many types of podcasts are found on the Internet such as television podcasts, radio podcasts, classroom podcasts, and individual or group podcasts. Television podcasts, radio podcasts and classroom podcasts are existing programs and lectures turned into podcasts such as those created by VOA (Voice of America).

Research in podcast effect on EFL learners listening skill or comprehension has been investigated by many researchers Rahman et al. (2018) investigated he students' interest towards podcast in the process of teaching listening comprehension on sixty students chosen from the eleventh grade students of the science department at SMU Negeri 1 Luwu in 2017/2018 academic years. The result of openended question analysis highlighted that podcast was attractive in the teaching and learning of English as a foreign language listening comprehension. Moreover, Silmawati (2018) investigated Podcasts with PeerAssisted Learning into English on students' listening comprehension on male and female tenth grade students at SMAN 7, Aceh Barat Daya. The result of this study was Podcast with PAL can be considered as an effective alternative technique for improving students' listening comprehension achievements.

According to Stanley (2005), Students can use podcasts as a supplement to their textbook materials. Warschauer and Healey (1998) states that integration of computerassisted language learning (CALL) technology helps learners learn language in a real, meaningful, authentic situation. The sociocognitive view of language learning stresses real language use in a meaningful, authentic context. Most of the podcasts found on the Internet are considered real and authentic. Computer-based podcasts can deliver combinations of text, sound, still images, graphics, animations, video and so on. Moreover, the interactionists believe that the basic element for successful language acquisition is input. Krashen (1985) states that language is acquired in only one way by receiving comprehensible input, that is, by understanding messages. Several CALL research studies carried out within an input perspective have attempted to explain the meaningful input from podcasts that is helpful for learners.

\subsection{Podcast and Types of Podcast}

The first podcasts appeared in early 2005. Podcast is surely easy to access, it would be attractive, and it motivates the students in learning. The podcast, an uploading audio or video file to the internet, has emerged as sources in the academic field, and it provides many kinds of material in learning. The podcast is a recorded audio/video file uploaded to a website, so the website users can download freely and listen to it later time. Kavaliauskiene (2008) states that podcasts have given the language teacher numerous materials for teaching. Besides, Rosell-Aguilar and Fernando (2015:38) claim, a podcast is similar to a public library that delivers any materials or resources needed straight to users devices. Users can download it freely without any registration and no fees required. They can choose a kind of discussion topics that was provided when they want to know something.

There are different types of podcast available on the internet. Currently, there are three types of podcast being produced and widely used that are classified by the format of content: audio podcast, enhanced podcast and video podcast (Bolliger et al., 2010; Shoar et al., 2011; Sze, 2006). Audio podcast is the most popular and easiest to use. It contains audio only and requires a small storage space. Mostly, it is in MP3 format and can be played using all MP3 players. Different from audio podcast, enhanced podcast is a combination of audio and 
digital images. Meanwhile, video podcast contains audio and video in one format. Usually, video podcast is produced in MP4 format and require larger storage space.

1.2.Mobile Learning and Using Podcasts as Language Learning Objects

Developments in IT and digital technologies have created a new academic ecosystem and have promises for "tomorrow's environment for learning" (Witherspoon, 2005:3). According to Witherspoon "Technology is changing everything from pedagogy to system-wide decision-making". Digital technology has promising potentials for language learning, but this does not mean that it simplifies the process. Novel applications may add new challenges to the complex process of foreign language instruction. According to Yang and Chen (2007) new applications require learners to adopt new learning strategies and teachers to take new additional roles.

Podcasting aims to distribute content to be used with mobile and digital audio/video players such as iPods including all other MP3 players, cell phones and PDAs." Podcasts are used to learn foreign languages and there is a huge amount of free content on the internet. According to Rosell-Aguilar (2013) the impact of podcasting on language learning is similar to that of the arrival of the Internet. Bausell (2006) claim that pop-culture literacy practices are adopted to radical degrees and stress that the use of podcasting as an alternative means of student expression has significant pedagogical potential. He believes that podcasts can be effective tools to integrate with the target culture and enable students gain a sense of group membership and thus overcome social and psychological barriers such as low selfesteem, anxiety and poor motivation. Podcasting and using podcasts in foreign language instruction, on which the present study is based, is a recently developed subfield of mobile learning.

Based on Oberg and Daniels (2013) states the use of mobile phone technologies brings new promises for the teaching and learning of languages. There are noteworthy potential gains that these mobile advices can bring to language learning. The mobile digital technology devices such as MP3 players, iPods, iPads, and smart mobile phones could offer their users the opportunity to access information almost anywhere, at any preferred time and at their own pace. For the last, Technology offers indispensable learning spaces and venues in the field of language learning. Podcasting, an evolving technology that supports digital recordings to be easily posted to the Internet for downloading to a personal audio player, may open broader doors to enhance language-teaching process and to effectively aid student learning. Podcast is one of mobile technologies, which is a combination of two words: iPod (Apple's MP3 player) and broadcast (Rosell-Aguilar, 2013). Podcasting refers to selecting and receiving podcasts that offer the users the advantage of freely controlling where, and when they listen to audio or video content.

\subsection{Listening Skill}

Hasan and Hoon (2013) have explained that listening skill allows the listener to give responses to the speakers during the learning process. To get those listening is an important aspect in communicating with others. Gann and Bufton (2012) stated that listening is used more than $45 \%$ in communication, which clearly shows how important this skill is in overall language ability. In recent years when listening is examined in relation not only to skill but also to language learning, listening has been considered from a further perspective. Teaching listening needs a bit more on the part of the teacher than that of the learners. One of the main principles of teaching listening is that language material should be intended to use for training listening Skill and it should never be presented visually first. The students really need to practice and improve their listening Skill. However, many students are uneasy when they have to practice listening skills because they have to listen carefully, focus, comprehend 
and remember what they have heard at the same time.

\section{METHODOLOGY}

This study used a case study design. It is enabling the clarity of an idea and principle which can fit together (Cohen et al., 2007). The issue addressed in this study was gaining a deeper investigation, the problems that the students encountered in using podcast and also how the students' listening Skill was influenced by podcast. The participants involved in this study were fourteen students of second semester on Tadris Bahasa Inggris Sekolah Tinggi Agama Islam Negeri Mandailing Natal. Although all of the students did not have any experience in using podcast for learning English before, but they had familiar with internet, youtube so on.

The first instrument in this study was questionnaire. Questionnaire was the first instrument used in this study. It is appropriate to investigate attitudes, perceptions and opinion (Cohen et al., 2007). In this study, the type of the questionnaire used was questionnaire. The close-ended questionnaire was analyzed qualitatively by using Likert Scale. In the Likert scale there were five categories of items in each statement. Those categorizes were strongly agree (SA), agree (A), fair (F), disagree (D) strongly disagree (SD). However, in this study, the questionnaire consisted of four predetermined answer where there was no option for fair. This to convince the tendency of participants in choosing the statements that was to agree or disagree. To complete the questionnaire, the participants needed to mark predetermined answer that represented their feeling about the topic included in the statements in the scale. There are number 1 until 5 which aims to investigate the advantages of podcast in influenced students' listening skill and also for number $6-10$ which aims to investigate the students' perception towards the use of podcast.
The second instrument in this study was interview. Interview was addressed to obtain data to support and clarify the data gained from the questionnaire. The aim of this model was to find the problems openly where the respondents were asked to give their opinion and ideas. The interview was conducted with three students as samples which were video recorded by a smartphone. There were four questions in the interview. The first and second questions were attempted to support the data concerning to the students' perception towards the use of podcast in listening skill. Meanwhile, the third and the fourth question were attempted to what they had listening and the problem when using podcast.

\section{FINDINGS AND DISCUSSION Findings}

The findings of this study was containing of data analysis. According to Berg and Lune (2012), the data analysis of the data was elaborated descriptively since the characteristic of a case study that is to describe and explain an event or phenomena systematically. At the beginning of the study, the participants were informed about podcast and where to get it. The students were given a list of websites where they can listen or download podcast from those websites. The students were also told how to get podcast from other resources such as from goggle and podcast application on their mobile phone.

\subsection{Questionnaire analysis}

The first step in analyzing the questionnaire was calculating the percentage of each total frequency of the students' answer to items by using percentage formula. It helps to classify the total respondents who answer the items. Then, the result of the questionnaire was interpreted descriptively. The data concerning to the students' perception of the advantages of podcast in their listening skill. To get the data clearer, the study analyzed the statements into percentage category. 
Table 1. The Result of the Advantages of Podcast in Influenced Students' Listening Skill based on Students' Perceptions

\begin{tabular}{|c|c|c|c|c|c|c|}
\hline \multirow{2}{*}{ No } & \multirow{2}{*}{ Question } & & \multicolumn{4}{|c|}{ The Percentage for each Stage } \\
\hline & & SA & $\mathrm{A}$ & $\mathrm{F}$ & $\mathrm{D}$ & SD \\
\hline 1 & $\begin{array}{l}\text { I like } \\
\text { podcast to } \\
\text { improve my } \\
\text { listening } \\
\text { skill } \\
\end{array}$ & $100 \%$ & $0 \%$ & $0 \%$ & $0 \%$ & $0 \%$ \\
\hline 2 & $\begin{array}{l}\text { Podcast is } \\
\text { easy to } \\
\text { accessed } \\
\text { and } \\
\text { appropriate } \\
\text { for me }\end{array}$ & $71.42 \%$ & $14.28 \%$ & 0 & $0 \%$ & $0 \%$ \\
\hline 3 & $\begin{array}{l}\text { Podcast } \\
\text { gave me the } \\
\text { motivations } \\
\text { for me in } \\
\text { learning } \\
\text { English } \\
\text { especially } \\
\text { listening } \\
\text { skill }\end{array}$ & $64.28 \%$ & $14.28 \%$ & $7.14 \%$ & $0 \%$ & $0 \%$ \\
\hline 4 & $\begin{array}{l}\text { Podcast } \\
\text { gave me the } \\
\text { new } \\
\text { vocabulary }\end{array}$ & $42.85 \%$ & $28.57 \%$ & $14.28 \%$ & $14.28 \%$ & $0 \%$ \\
\hline 5 & $\begin{array}{l}\text { In podcast } \\
\text { we can } \\
\text { joint to } \\
\text { improve } \\
\text { our English } \\
\text { in comment } \\
\text { special } \\
\text { column }\end{array}$ & $0 \%$ & $50.00 \%$ & $14.28 \%$ & $21.42 \%$ & $14.28 \%$ \\
\hline 6 & $\begin{array}{l}\text { I think } \\
\text { listening is } \\
\text { easier with } \\
\text { using } \\
\text { podcast } \\
\end{array}$ & $57.14 \%$ & $42.85 \%$ & $0 \%$ & $0 \%$ & $0 \%$ \\
\hline 7 & $\begin{array}{l}\text { The podcast } \\
\text { is } \\
\text { containing } \\
\text { of authentic } \\
\text { text }\end{array}$ & $57.14 \%$ & $28.57 \%$ & $14.28 \%$ & $0 \%$ & $0 \%$ \\
\hline 8 & $\begin{array}{l}\text { I did not } \\
\text { need } \\
\text { podcast }\end{array}$ & $0 \%$ & $0 \%$ & $0 \%$ & $14.28 \%$ & $85.71 \%$ \\
\hline 9 & $\begin{array}{l}\text { My } \\
\text { listening } \\
\text { skill is lack, } \\
\text { I need the } \\
\text { media to } \\
\text { support it }\end{array}$ & $71.42 \%$ & $28.57 \%$ & $0 \%$ & $0 \%$ & $0 \%$ \\
\hline 10 & $\begin{array}{l}\text { Podcast } \\
\text { should be } \\
\text { implement } \\
\text { in listening } \\
\text { subject in } \\
\text { the } \\
\text { classroom }\end{array}$ & $85.71 \%$ & $14.28 \%$ & $0 \%$ & $0 \%$ & $0 \%$ \\
\hline
\end{tabular}

From the first statement was about students' feeling about podcast. In Table 1 shows that all of the students $(100 \%)$ who strongly agree that they like podcast. This finding is in line with $\mathrm{Li}$, (2009) who stated that students have their willingness to use podcast on their improving listening skill in the learning English.
Then, the second statement was about students' satisfaction in accessed and appropriated podcast in internet. There are some students are the new one in podcasting. In table 1 show that almost students (71.42\%) strongly agreed that podcast is easy to accessed and it appropriate for them when they want to listen the native English speaker in their daily. There are (14.28\%) of students agreed about it. It also means that some of students had difficulties to accessed podcast by them self.

The next, the third statement was about students' motivation in learning English after listening to podcast. Table 1 shows that a large number of the students (64.28\%) strongly agreed and small number of the students $(14.28 \%)$ agreed that podcast motivate them in learning English. There is one student is fair about podcast give him the motivation in listening. This means that podcast can motivate the students in learning English. In line with that, Bolliger et al. (2010) stated that students were also motivated by the use of podcast that was integrated into online learning.

The fourth statement was about the students' achievement in the new vocabulary from podcast. Table 1 shows that a small number of students $(42.85 \%)$ strongly agreed, it added with only some student (28.57\%) agreed, overtaken by a small number students (14.28\%) fair and also disagreed with the same number. It means that vocabulary still difficult mastered by students just listening in once. It must be again and again. Although, audio listening is a great tool to achieve the objective. So the lecturer should be creative for presenting the material.

For the fifth statement, table 1 was present zero $(0 \%)$ number of student in percentage. A half of students (50\%) agreed that podcast can joined students to give some comment special column so the students can improve their writing and speaking skill also. But only small number of them are were brave to show up. In addition, a very small number of students (14.28) fair or neutral answered. The last was disagreed answer. It was around 
$(21.42 \%)$ and there are small number strongly disagreed answers. This means that some students might have problems in using podcast and their English is still lack vocabulary.

For the sixth statement, table 1 showed that more than a half of the students (57.14\%) agreed and a small number of the students $(42.85 \%)$ strongly agreed with the statement that listening is easy with using podcast. This indicates that most of the students agreed that podcast can help students in listening.

The seventh statement was about whether podcast can help students in learning English. It refers to the statement that the podcast are containing of authentic text from the interviewee and native speaker. Table 1 shows that more than a half all of the students $(57.14 \%)$ strongly agreed and a small number of the students $(28.57 \%)$ who answer agreed with the statement. Besides that, there is two students $(14.28 \%)$ fair or neutral answer. There was no student who disagreed or strongly disagreed with the statements. This means that podcast are containing the authentic one as the sources (RosselAguilar, 2013)

The next statement, the eight one was about podcast is not needed by students in listening. In table 1 , there is no students states strongly agreed and agreed. Almost all students answered strongly disagreed $(85.71 \%)$. Only around $(14.28 \%)$ answered disagreed. It means that podcast is very important and useful in learning English.

The ninth statement was about suitable with the previous statement, in this part the students' listening skill are lack, so their need the media to support the problem. Almost students $(71.42 \%)$ answered strongly agree and a small number of students $(28.58 \%)$ was agreed about this problem. There is no students disagreed with this statement.

The last statement was whether they agree if podcast should be implemented in the classroom activity. Table 1 showed that more than half of the students strongly agreed
(85.71\%) that podcast should be implemented in the classroom activity and only small number of the students $(14.28 \%)$ agreed with the statement. This can be a good suggestion for teachers to implement podcast in teaching and learning activity. As Copley (2007) suggest that the use of podcast can be more effective if it is thoughtfully integrated into curricula.

\subsection{Interview Data}

The interview was conducted with three students as samples which were video recorded by a smartphone. There were four questions in the interview. The findings from questionnaire were supported and clarified by using oral interview. In this part, the discussion of the data is about students' perceptions towards the use of podcast in learning English. Based on the interview, most of the students had positive perceptions towards the use of podcast to support listening skill. The specific elaborations are as follows.

The first question related to the student's feeling in using podcast. The students were asked whether they pleasured in listening to podcast. All students said that they like listening to podcast. In relation to this, N.I.N, one of the students, stated that:

"tau miss, itu yg video ato rekaman kan miss, saya suka miss dengarkan karena banyak kali gunanya buat belajar bahasa miss, terutama untuk listening kan, punya saya ada channel $B C C$, disitu ada juga bentuk teks yang buat reading jugak",

(I see mrs, it can be video or recorded, I like listen podcast contain because so many usage for English learning, especially for listening, I have BBC channel, there is a text form for reading skill)

Another students, N.A.P, stated that:

"saya tahu dan sering download podcast itu miss, saya sukak kali lho miss, bagus buat belajar, apa lagi yang podcastnya orang luar negeri kan miss, penutur asli, jadi bisa awak belajar buat dengar banyak kosa kata baru” 
(I know it and I usually download podcast Mrs. I like it very much Mrs. It is good for ELT, moreover it is from British or American, the native speaker there are, so I can listen well and I achieved the new vocabulary)

Besides that, any one sample, here are the interview result from I.M, stated that:

"saya baru satu bulan ini sih miss suka liat podcast, itu pun yang dedi coubuzir punya miss, tapi ini karena udah tau yang bahasa inggris rupanya banyak kali manfaatnya ya miss, belajar banyak saya jadinya, khususnya mendengarkan bahasa inggris miss".

(I am the new one in podcast user mrs. Around one month later. I like podcast, it is dedi corbuzir belongs to, but because I've already know in English version, in a fact we have easier to learn English, I can more comport especially in listening.)

This indicates that podcast is still very new for the students. Thus, it is important to inform the students about how to use podcast and suggest more resources of podcast for the importance of learning. In line with that, Yeh (2013) suggests that "Teachers should first familiarize themselves with the technology and available resources in order to introduce learners to the basics of podcasting".

The next question was used to gain the data regarding to the students' problems in using podcast. The students were asked about their problems in using podcast. The most crucial problem investigated in this study was about the length of podcast that was too long for them. One of the students, N.I.N., stated that:

"banyak dapat kita pembelajaran miss dari podcast, Cuma kadang kan miss karena saking panjang nya durasinya bikin bosan juga kan miss, jd paket pun ngak cukup miss, kalo download pun $g$ muat lagi penyimpanan $H P$ awak kan miss... hehehehe kalo mengaksesnya gampang ny memang miss, banyak channel nya kok langsung dapat nya di playstore miss"

(so many lesson were from podcast, but sometimes because it is a length duration video or recorded, so it took many internet quota and I'd bored, that is the problem for me Mrs. If I download it, I also had the problem for my storage.... Hehehehhe. if you want to search the channel, it is easier right in playstore).

In another sample, it is from N.A.P. stated that:

"kalo mau nonton, dengar dan download memang gampang miss, Cuma yang jadi masalah kan kuota internet, wifi disini gak ada miss, jaringan juga susah kadang mau ikut belajar daring juga kadang harus jauh dari rumah, tapi diusahakan selalu unduh satu video buat ditonton dirumah"

(if you want to watch, listen and download. It fair for all students. But the problem is about the internet connection, quota and there is no supported large internet connection here (wifi). Sometimes in online class I also had the problem, but I usually download one of video and I watch in my home.

From the students' statements above it was found that the duration of podcast available in the internet is too long for them. The students might feel heavy if they listen to an English recording with a long duration. Therefore, podcast file should be kept in short in order to maintain students' interests and focuses (Bolliger et al., 2010). The big problem was about students' facilities in getting the podcast from internet. As podcast available online, so the internet access is needed to download podcast. For some students, they might have problems for downloading and having access to podcast including: there was no internet access, slow internet speed, lack of cell phone signal in their area and not being able to afford a sophisticated cell phone or laptops (Farshi and Muhammadi, 2013).

There are various types of podcast that are available on the internet produced by many websites. The study found that this fact brought more enthusiasm for students in listening to podcast. However, for some students, this can be a problem because they found it hard to find a podcast that they like. In order to match with the students' context, teachers do not need to download podcast solely from the internet. lecturer can design their own podcast that 
matched with students' level of materials. The used of visual image and transcript text can also be provided in teachers-made podcast.

Besides giving the students a freedom to choose the podcast and listen to it on their own gadgets, it would be better for lecturer to bring podcast into the classroom activities. In addition, Podcast also tended to contain unscripted authentic material which makes the students confused because they cannot follow the whole conversation.

\section{DISCUSSION}

This study was aimed at finding out whether the use of podcast media in teaching was motivated students' listening skill. As described in the research background, that students had known the podcast was encouraging students to listening topics through podcast can activate students' engagement in listening practices with podcast for exchanging ideas in relation to find alternative solution. Students are ready to communicate related the topic because previously they enrich their ideas from listening podcast and connect the topic with their real-life situation. Crawford (2007) found that podcasting can be applied to build different literacies because of its multimodal communication approach. A podcast contains various components depending on the type podcast being opened. Some podcasts are using audio only, or might be completed with visual simulation. Other podcasts offer students with a mix of audio and visual texts, while other podcasts are a combination of audio and still pictures. Depending on the type of podcast being used, different components of the technology may be more useful to users based on literacy favorites or major intelligence level. As said early, participants enjoyed two different types of podcasts, one's audio sense and more visually stimulating.

Based on the results of the questionnaire and interview, it was found that there were finding showed that most of the students viewed podcast in a positive way. This finding was supported by most of the studies in this topic. Moreover, podcast motivated students in learning especially in E-learning environment. Compare with conventional listening records that are usually used by teachers, podcast provides more benefits and excitements for students. Therefore, besides giving the students a freedom to choose the podcast and listen to it on their own gadgets, it would be better for teacher to bring podcast into the classroom activities. In addition, Podcast also tended to contain unscripted authentic material which makes the students confused because they cannot follow the whole conversation.

\section{CONCLUSION}

The findings and discussion showed students agreed that podcast could help them in learning English and they have willingness in using podcast as a media for students' listening skill. They like podcast very much and they had positive attitude for using it. Because, podcast was motivated them. It was engaged their interest about the content of the podcast and clear native pronunciation derived from podcast. Besides that, most of the students also agreed that podcast was easy to get since there are many podcasting websites available on the internet. In the findings, this present study has led us to conclude that the podcast had the huge potential to help learners in improving their listening skill.

\section{REFERENCES}

[1] Bausell, S. B. (2006). Pump up the pod: Popular culture and podcasting in a critical secondary language arts course. Master of Education Thesis. University of Hawai'i. UMI Number: 1435698.

[2] Berg, B. L., \& Lune, H. (2012). Qualitative research method for the social sciences. (Eight edition). US: Pearson. 
[3] Bolliger, D. U., Supanakorn, S., \& Boggs, C. (2010). Impact of podcasting on student motivation in the online learning environment. Computers and Education, 55(2), 714-722.

http://doi.org/10.1016/j.compedu.201 0.03 .004

[4] Cohen, L., Manion, L., \& Morrison, K. (2007). Research methods in education (Six edition). New York: Routledge.

[5] Crawford, C. (2007). Podcasting and Video Integration into the Learning Environment. International Journal of Learning, 13(9), 39-48.

[6] Gann, D. A., \& Bufton, N. A. (2012). Critically Minded Podcasts: An interactive Curriculum. JaltcallJournal , 233-242.

[7] Hasan, M., \& Hoon, T. B. (2013). Podcast Applications in Language Learning: A Review of Recent Studies. English Language Teaching, 6(2), 128-135.

[8] Kavaliauskiene, G. (2008). Podcasting: A tool for improving listening skills. The Journal of Teaching English with Technology (TEwT), 8(4). Retrieved from http://www.tewtjournal.org/VOLln8/ISSU E\n4/A \nWORD $\operatorname{lnFROM\backslash nA\backslash nT}$ ECHIE.pdf

[9] Krashen, S. (1985). The Input Hypothesis: Issues and Implication. Longman: New York.

[10] Li, H. C. (2009). Using podcasts for learning English: Perceptions of Hong Kong Secondary 6 ESL students. 78-90.

[11]Marshall, J. M. (2002). Learning with technology: Evidence that technology can, and does, support learning. California: Cable in the Classroom.

[12] Oberg, A., \& Daniels, P. (2013). Analysis of the effect a student-centered mobile learning instructional method has on language acquisition. Computer Assisted Language Learning, 26(2), 177-196. doi:10.1080/09588221.2011.649484

[13]Rahman, A., Atmowardoyo, H. and Salija, K. (2018). Podcast Effects on EFL
Learners Listening Comprehension. Retrieved from International

[14] Journal of Applied Linguistics \& English 1(4), 216-229. https://doi.org/10.7575/ijalel.v.1n.4p.216

[15] Rossel-Aguilar, F. (2013). Podcasting for language learning through iTunes U: The learners' view. Language Learning \& Technology, 17(173), 74- 93. Retrieved from

http://1lt.msu.edu/issues/october2013/rosel laguilar.pdf

[16] Samad, I.A \& Fitriani, S.S (2016). English proficiency: A challenge and an opportunity in facing ASEAN Economic Community. Proceeding of Annual International Conference, Syiah Kuala University, 5-6 October. Banda Aceh: University Press

[17] Silmawati, Muslem, A and Samad I.A. (2018). Podcast with Peer Assisted Learning: does It Really Affect Students' Listening Comprehension Skills?. English Education Journal (EEJ), 9(3), 490-500, July 2018

[18] Stanley, G. (2005). Podcasting for ELT. Retrieved from http://www.teachingenglish.org.uk/think/r esources/podcast.shtml

[19] Warschauer, M., \& Healey, D. (1998). Computers and language leaning: An overview. Language Teaching, 31, 57-71.

[20] Witherspoon, J. (2005). Building the academic eco-system: Implications of elearning. International Journal of Instructional Technology and Distance Learning, 3(3), 3-12.

[21] Yang, S.C. and Chen, Y. (2007). Technology-enhanced language learning: A case study. Computers in Human Behavior, 23, 860-879.

[22] Yeh, C. (2013). An investigation of a podcast learning project for extensive listening. Languaged Education in Asia, 4(2), 135-149. Retrieved from http://www.camtesol.org/Download/L EiA_Vol4_Iss2_2013/LEiA_V4_I2_A4 
Yeh_Investigation_of_Podcast_Learning

Project_for_Extensive_Listening.pdf

[23] Young, C. (2003). Integrating ICT into second language education in a vocational high school. Journal of Computer Assisted Learning, 19, 447-461. 